\title{
Vertical distribution of scuttle flies (Diptera: Phoridae) in a beech forest
}

\author{
Carlos GARCÍA-ROMERA and Jose Antonio BARRIENTOS
}

\author{
Departamento de Biología Animal, de Biología Vegetal y de Ecología (Unidad de Zoología), Facultad de Ciencias, \\ Universidad Autónoma de Barcelona, E-08193 Bellaterra, Barcelona; Spain \\ Corresponding author.e-mail: cgarci24@xtec.cat
}

\begin{abstract}
The structure of scuttle fly communities in vegetative strata of a beech forest in the Montseny Natural Park (Catalonia, Spain) was compared. Window traps were used from March 1990 to March 1991. Relative abundance and species richness of scuttle flies were higher in the herb and shrub layers than in the canopy, while diversity was not significantly different between strata. Saprophagous species dominated in all strata, while the mycophagous and zoophagous species decreased with height. Herb layer was dominated by Megaselia pectoralis and M. subpleuralis. Shrub layer was dominated by M. pectoralis, M. pectorella, M. diversa, M. subpleuralis and M. superciliata. Canopy layer was dominated by M. pectorella, M. pectoralis, M. pusilla and M. diversa.
\end{abstract}

Key words: Phoridae, Montseny, Spain, beech forest, vertical distribution, trophic groups

\section{INTRODUCTION}

Phoridae, a very diverse family in the order Diptera, include about 4,000 species distributed nearly 260 genera. It is one of the families of Diptera with the highest diversity of larval life forms, with saprophages, predators, fungivores, parasits or parasitoids species (Disney 1990, Disney et al. 2010).

There are only a few studies on the vertical distribution of Diptera communities in European forests (e.g. Pollet \& Grootaert 1991, Kampichler \& Teschner 2002). Most of surveys have traditionally analysed the scuttle fly communities of a single stratum (i.e. herb layer) by using emergence traps, pitfall traps, yellow traps and Malaise traps, placed directly on the floor (e.g. Buck 1994, 1997; Durska et al. 2010; Durska 2015). Only a few works assess the Phoridae of tree canopy using yellow traps attached to the trunks of the trees, but without comparing the results with lower levels (Durska 1996, 2001, 2006), so no previous surveys show the vertical distribution of scuttle fly communities in European forests.

The objective of this study is to analyse the vertical distribution of the scuttle fly communities in a beech forest of the Montseny Natural Park (Catalonia). In the deciduous forest studied there was rich litter and decaying organic matter in the soil. Therefore, the dominance of saprophagous species was expected, and thus, lower strata should be richer and more abundant with scuttle flies than higher. The hypothesis of a higher abundance and species richness in the lower strata than upper was tested.

The global scuttle fly data obtained in the survey of the Montseny Natural Park is given by García-Romera \& Barrientos (2014a). The new species captured have been described in the paper by García-Romera \& Barrientos (2014b). 


\section{STUDY AREA}

The Montseny massif presents a wide variety of climatic conditions, environments and species, so its protection is of great importance. It was declared biosphere reserve by the UNESCO in 1978 and Natural Park in 1987. It is located in the provinces of Barcelona and Girona, it covers about $400 \mathrm{~km}^{2}$ and its highest peak reaches 1,712 m (Boada \& Ullastres 1998; Boada 2001). Dominant plant communities are the holm oak (Quercus ilex L.) (up to $900 \mathrm{~m}$ ) and beech (Fagus sylvatica L.) (from 1,000 to 1,500 m) forests, and scrublands of Juniperus communis L. and Calluna vulgaris L. (above 1,500 m).

Three plots were selected in the Montseny Natural Park belonging to the acidophile beech forest (ass. Luzulo Niveae-Fagetum). Two plots were on humid soil, at 1,130 m a.s.1. (UTM 31TDG530274) and at 1,170 $\mathrm{m}$ a.s.l. (UTM 31TDG532273), while the third plot on dry soil at 1,250 m a.s.1. (31TDG540279 UTM).

\section{SAMPLING METHODS}

Samplings were conducted from March 1990 to March 1991, every fortnight. The sampling method used in the three plots were window traps. Each interceptor had a transparent glass of $0.80 \times 0.40 \mathrm{~m}$ (width, height), with a collector plate on each side with $4 \%$ formaldehyde and detergent. The material to identification was preserved in $70 \%$ ethanol.

Vertical distribution of scuttle flies was analysed on the basis of material derived from eight window traps placed in three plots at herb level $(0.10-0.50 \mathrm{~m}$; one on each plot $)$ and shrub level (0.90-1.30 m; similarly: one on each plot) and from two traps placed in a humid plot (1,130 $\mathrm{m}$ a.s.1.) at the canopy level $(6.00-6.40 \mathrm{~m}$ and $11.00-11.40 \mathrm{~m})$. Traps of herb and shrub strata were subject attached on a same stand anchored in the ground, while those located in canopy stratum were subject attached laterally to a $12 \mathrm{~m}$-high tower.

\section{DATA ANALYSIS}

Analyses were only based on males, as most females of genus Megaselia Rondani, 1856 and Phora Latreille, 1796 are not identifiable at species level.

Since the sampling effort varied between periods, we standardized the abundance to the number of individuals who fell into a trap in one day to make the fortnight samples comparable.

We used the index of dominance (D) to compare scuttle fly assemblage structures:

$$
D=\frac{n_{i}}{N} \cdot 100
$$

where $n_{i}$ is the number of individuals of $i$ species in a sample, $N$ is the number of individuals of phorid community in a sample.

Dominant species were considered when the index of dominance was $>1 \%$ and accessory (rare) species when it was $\leq 1 \%$.

Species diversity was quantified using the Shannon index $\left(H^{\prime}\right)$ :

$$
H^{\prime}=-\sum p_{i} \ln p_{i}
$$

where $p_{i}=n_{i} / N$ (relative abundance).

The differences in the scuttle fly relative abundance among the three strata in the beech forest were assessed performing a PERMANOVA analysis with repeated measures (for fortnight samples) (Anderson 2001). The samples in three plots were taken as replicates in each lower level (herbs or shrubs) and the samples of two upper levels in the humid beech forest were the replicates of canopy level because the prior analysis of the Phoridae didn't show differences between two upper levels. A PERMDISP routine was done for testing the 
homogeneity of dispersions between habitats. However, we consider that a non-significant result from PERMDISP ( $p>0.05$ ) is not strictly necessary prior to using PERMANOVA. The analyses was based on two-factors design, one fixed (stratum with three levels) and other random (time). The differences in species richness, diversity (Shannon index) and abundance of species ( $>100$ individuals) among strata were analysed using PERMANOVA analysis with repeated measures with these factors fixed, and the time a random factor. The statistical pseudo-F and p-value in the permutation test were calculated after 9,999 permutations. When the main test was significantly different, it was performed pair-wise comparisons among all pairs of strata; it used the $t$ statistic, the square root of pseudo-F. In all analysis, Euclidean distance was used as resemblance measure and significant level was set at $p=0.05$. Test were performed using the PERMANOVA + for PRIMER software (Anderson et al. 2008).

\section{RESULTS}

We identified a total of 6,115 individuals belonging to 158 scuttle fly species. The number of individuals and species decreased from herb to canopy layer. Therefore, the mean number of individuals $(N)$ and species $(S)$ per plot in herb stratum $(N=938, S=78)$ were almost the same than in the shrub stratum $(N=890, S=70)$. However, lower number of individuals $(N=316)$ and species $(S=41)$ per sample were identified in the canopy stratum.

The mean relative abundance of scuttle flies was significantly different between strata in the main test (pseudo-F $=4.3414, p=0.0192$ ), with homogeneity of dispersions $(p=0.0669)$. The relative abundance of scuttle flies in canopy stratum was significantly lower than in another two strata (herb-canopy, $\mathrm{t}=2.933, \mathrm{p}=0.048$ and shrub-canopy, $\mathrm{t}=2.9249, \mathrm{p}=$ 0.0097), but it wasn't different between herb and shrub layers $(t=0.6646 ; p=0.5225)$ (Fig. 1).

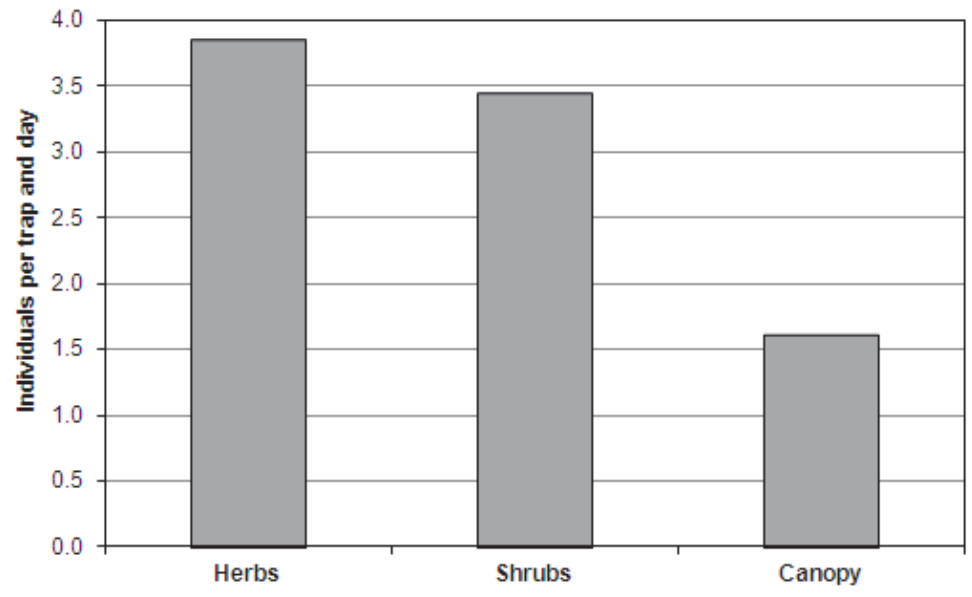

Fig. 1. Mean relative abundance of scuttle flies in different strata of the studied beech forest plots.

Species richness was significantly different between strata in the main test (pseudo-F = $5.7654, p=0.0093)$, although without homogeneity of dispersions $(p=0.0272)$. The species richness of the canopy layer was significantly lower than in the herb layer $(\mathrm{t}=2.5668 ; \mathrm{p}=$ $0.0242)$ and in the shrub layer $(t=2.8292 ; \mathrm{p}=0.0169)$, however it wasn't different between the herb and the shrub layers $(\mathrm{t}=1.3586 ; \mathrm{p}=0.201)$. In the main test, diversity (Shannon index) wasn't significantly different between strata (pseudo-F $=3.2343, \mathrm{p}=0.0514$ ) (Fig. 2). 


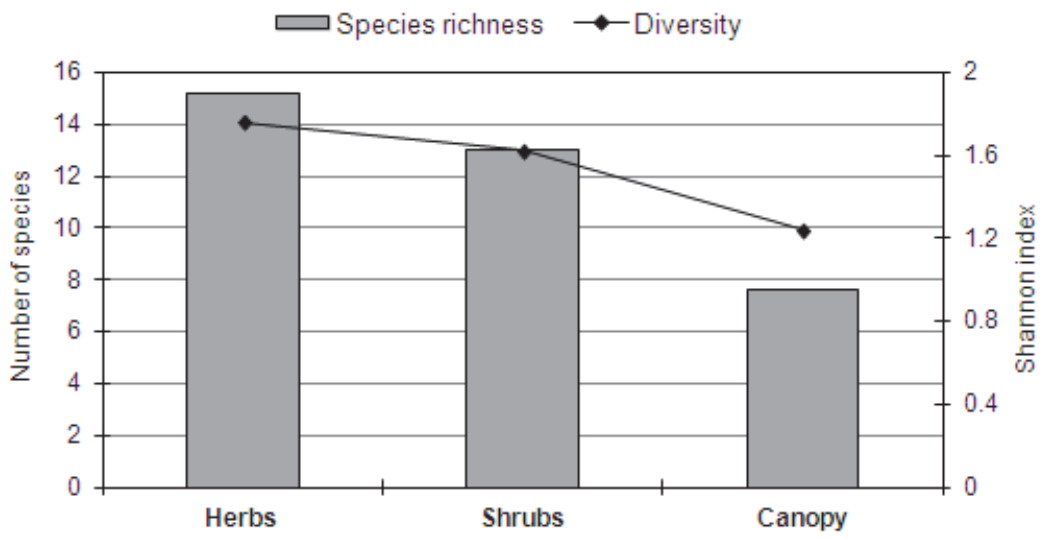

Fig. 2. Mean species richness (number of species) and diversity (Shannon index values) of scuttle flies collected in different strata of the studied beech forest plots.

Larval habit is known for only about $60 \%$ of the collected species. The saprophages were the most abundant trophic group in all the strata, followed by the polyphages. Likewise, the number of individuals of zoophages and mycophages decrease with the height (Table 1, Fig. 3a). There were no differences in the species richness among strata by trophic groups. However, the zoophages had a greater number of species in the two lower levels (Table 1, Fig. $3 b)$.

Table 1. Average number of individuals (N) and species (S) per trap of scuttle flies by trophic groups and strata in sampling year

\begin{tabular}{lrrrrrr}
\hline \multirow{2}{*}{ Stratum } & \multicolumn{2}{c}{ Herbs } & \multicolumn{2}{c}{ Shrubs } & \multicolumn{2}{c}{ Canopy } \\
\cline { 2 - 7 } Trophic group & \multicolumn{1}{c}{$\mathrm{N}$} & \multicolumn{1}{c}{$\mathrm{S}$} & $\mathrm{N}$ & $\mathrm{S}$ & $\mathrm{N}$ & $\mathrm{S}$ \\
\hline Saprophages & 436.33 & 17.33 & 309.66 & 13.67 & 196.00 & 14.50 \\
Polyphages & 91.33 & 7.33 & 78.67 & 7.33 & 45.00 & 6.50 \\
Mycophages & 64.33 & 12.00 & 38.00 & 10.33 & 14.00 & 8.00 \\
Zoophages & 18.33 & 4.33 & 6.67 & 4.33 & 3.00 & 1.50 \\
$\quad$ Total (known species) & 610.33 & 41.00 & 433.00 & 35.67 & 258.00 & 30.50 \\
\multicolumn{1}{r}{ Unspecified } & 327.67 & & 456.33 & & 58.00 & \\
\hline
\end{tabular}

Two species clearly dominated in the herb stratum: Megaselia pectoralis (Wood, 1910) and M. subpleuralis (Wood, 1909), with a accumulate index of dominance about $45 \%$, other six species were collected with percentage more than $3 \%$, including $M$. diversa (Wood, 1909), $M$. pectorella Schmitz, 1929 and M. pusilla (Meigen, 1830). Five species: M. subpleuralis, M. pectoralis, M. pectorella, M. diversa, and M. superciliata (Wood, 1910) dominated in the shrub stratum accounting more than $65 \%$ of all scuttle flies. Four species dominated in canopy stratum: M. pectorella, M. pectoralis, M. pusilla and M. diversa, accounted for about 58\%. (Table 2). Significant differences between strata were revealed for five species in their mean abundance. M. subpleuralis and M. longicostalis (Wood, 1912) had a greater abundance in the shrub layer, while they were represented by only a few individuals in the canopy layer. Diplonevra florescens (Tuton, 1801) was more abundant in the herb layer. The dominance of M. pectoralis and M. lata (Wood, 1910) decreased with the height. The abundances of another five species were not significantly different between strata. However, M. pectorella was the 
only species that had a higher abundance in the shrub and canopy layers than in the herb layer, although without statistically significant differences between strata (Table 3).

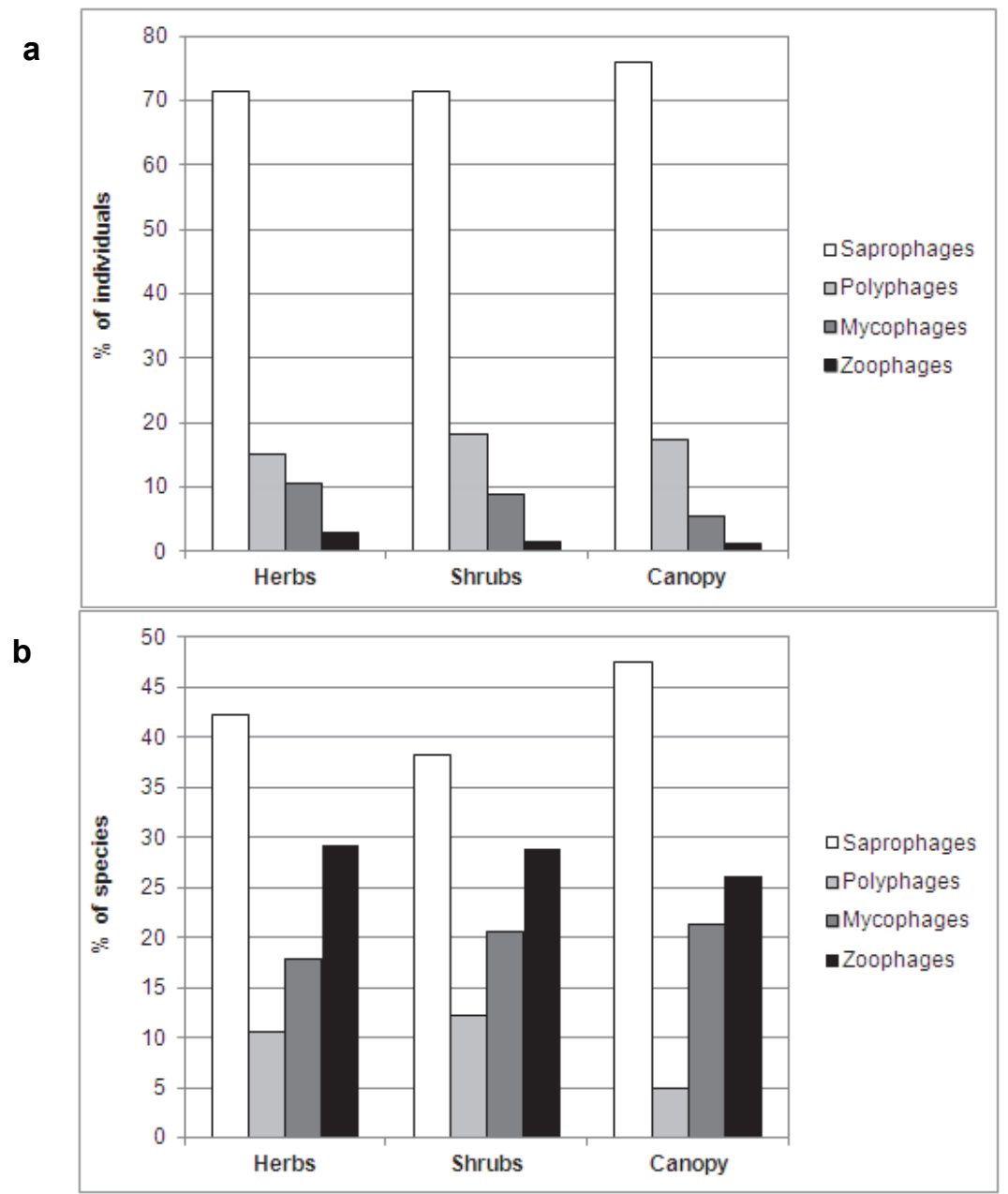

Fig. 3. Mean percentage of trophic groups of scuttle flies collected in different strata of the studied beech forest plots, in relation to individuals (a) and species (b).

\section{DISCUSSION}

We found a higher activity and species richness of scuttle flies in the herb and shrub strata of beech forest. Most species in this habitat are saprophagous or mycophagous, with larvae that live mainly in soil. Adults continue their activity near their emergence site, visiting flowers or feeding on other dead insects or decaying litter. However, the most saprophagous species emerge in herb stratum (soil), but they were dominants in all strata. Their presence in the canopy layer could be casual, as a place for mating or feeding on the honeydew of aphids (Disney 1994). 
Table 2. Dominance structure of scuttle flies species (with $\mathrm{D}>1 \%$ ) in different strata.

\begin{tabular}{|c|c|c|c|c|c|}
\hline \multicolumn{2}{|l|}{ Herbs } & \multicolumn{2}{|l|}{ Shrubs } & \multicolumn{2}{|l|}{ Canopy } \\
\hline Species & $\mathrm{D}$ & Species & $\mathrm{D}$ & Species & $\mathrm{D}$ \\
\hline Megaselia pectoralis & $30.81 \%$ & Megaselia subpleuralis & $30.36 \%$ & Megaselia pectorella & $23.42 \%$ \\
\hline Megaselia subpleuralis & $14.78 \%$ & Megaselia pectoralis & $15.07 \%$ & Megaselia pectoralis & $22.63 \%$ \\
\hline Megaselia diversa & $3.80 \%$ & Megaselia pectorella & $10.16 \%$ & Megaselia pusilla & $7.12 \%$ \\
\hline Diplonevra florescens & $3.73 \%$ & Megaselia diversa & $5.55 \%$ & Megaselia diversa & $5.38 \%$ \\
\hline Megaselia pectorella & $3.73 \%$ & Megaselia superciliata & $5.13 \%$ & Megaselia angusta & $3.32 \%$ \\
\hline Megaselia superciliata & $3.52 \%$ & Megaselia basispinata & $3.04 \%$ & Megaselia subpleuralis & $3.01 \%$ \\
\hline Megaselia pusilla & $3.41 \%$ & Megaselia longicostalis & $2.85 \%$ & Conicera floricola & $2.85 \%$ \\
\hline Megaselia basispinata & $2.42 \%$ & Megaselia pusilla & $2.51 \%$ & Megaselia monochaeta & $2.69 \%$ \\
\hline Megaselia longicostalis & $2.31 \%$ & Borophaga femorata & $1.42 \%$ & Diplonevra florescens & $2.22 \%$ \\
\hline Megaselia lata & $1.95 \%$ & Megaselia lata & $1.42 \%$ & Megaselia basispinata & $2.06 \%$ \\
\hline Megaselia flavicans & $1.85 \%$ & Megaselia subtumida & $1.27 \%$ & Megaselia giraudii & $1.90 \%$ \\
\hline Megaselia monochaeta & $1.63 \%$ & Megaselia monochaeta & $1.16 \%$ & Megaselia aculeata & $1.42 \%$ \\
\hline Megaselia angusta & $1.60 \%$ & Megaselia pleuralis & $1.16 \%$ & Megaselia lata & $1.42 \%$ \\
\hline Diplonevra nitidula & $1.31 \%$ & Megaselia pedatella & $1.05 \%$ & Megaselia meconicera & $1.42 \%$ \\
\hline Megaselia scutellaris & $1.21 \%$ & & & Megaselia involuta & $1.27 \%$ \\
\hline Borophaga femorata & $1.10 \%$ & & & & \\
\hline In sum & $79.18 \%$ & In sum & $82.16 \%$ & In sum & $82.12 \%$ \\
\hline Other species $\left(\mathrm{D}_{\leq} 1 \%\right)$ & $20.82 \%$ & Other species $\left(\mathrm{D}_{\leq} 1 \%\right)$ & $17.84 \%$ & Other species $\left(D_{\leq} 1 \%\right)$ & 17.88 \\
\hline Total & $100.00 \%$ & Total & $100.00 \%$ & Total & $100.00 \%$ \\
\hline
\end{tabular}

Table 3. Comparisons of mean number of male individuals of dominant scuttle fly species per trap in each stratum with the results of main test and pair-wise comparisons in PERMANOVA analysis; * significant $p$-values at 0.05 ; in italics the homogeneity of dispersion by strata in the main test $(p>0.05$ in the PERMDISP analysis $)$; her $=$ herb layer, $\mathrm{shr}=$ shrub layer, can $=$ canopy layer.

\begin{tabular}{|c|c|c|c|c|c|c|c|}
\hline \multirow[b]{2}{*}{ Species $\backslash$ Strata } & \multicolumn{3}{|c|}{ Mean abundance } & \multirow{2}{*}{$\begin{array}{c}\text { Main test } \\
p \text {-value }\end{array}$} & \multicolumn{3}{|c|}{ Pair-wise comparisons } \\
\hline & her & shr & can & & her-shr & her-can & shr-can \\
\hline Megaselia pectoralis & 21.79 & 10.31 & 5.46 & $0.0226 *$ & $0.0404 *$ & 0.0682 & 0.1415 \\
\hline Megaselia subpleuralis & 10.36 & 20.64 & 0.73 & $0.0137 *$ & 0.1606 & $0.0256 *$ & $0.006 *$ \\
\hline Megaselia pectorella & 2.69 & 6.95 & 5.54 & 0.3832 & & & \\
\hline Megaselia diversa & 2.69 & 3.74 & 1.23 & 0.0929 & & & \\
\hline Megaselia superciliata & 2.51 & 3.49 & 0.23 & 0.1679 & & & \\
\hline Megaselia basispinata & 1.72 & 2.08 & 0.50 & 0.1609 & & & \\
\hline Megaselia pusilla & 2.46 & 1.72 & 1.00 & 0.1045 & & & \\
\hline Megaselia longicostalis & 1.62 & 1.95 & 0.15 & $0.0321 *$ & 0.4841 & 0.0888 & $0.0406 *$ \\
\hline Diplonevra florescens & 2.67 & 0.44 & 0.54 & $0.0315 *$ & 0.059 & 0.0887 & 0.674 \\
\hline Megaselia lata & 1.38 & 0.95 & 0.35 & $0.0113 *$ & 0.0941 & $0.0125 *$ & 0.1041 \\
\hline
\end{tabular}

The polyphages, that can use different resources, were found in similar percentage of individuals in each strata, although they were slightly more abundant in two upper strata.

The mycophagous species were trapped in less abundance in the upper strata, as the larvae feed on sporophores and mycelium from fungi, mainly closer to soil, and fungal spores could be a resource for adult of some species (Disney 1994).

The parasitoids (zoophages) were more abundant in lower levels because most their hosts inhabit in the soil, such as Megaselia aequalis (Wood, 1909) (parasitoid of slug eggs), M. annulipes (Schmitz, 1921), M. longifurca (Lundbeck, 1921) and M. nasoni (Malloch, 1914) (parasitoids of spiders or their eggs), M. mallochi (Wood, 1909) (parasitoids of Sciaridae pupae), M. elongata (Wood, 1914) (parasitoids of Diplopoda), Borophaga incrassata (Meigen, 1830) (parasitoids of Bibionidae larvae) and Diplonevra nitidula (Meigen, 1830) (parasitoids of earthworms). In addition, adults of some species are flower-visiting (Robinson 1971, Disney 
1994, 1999, Disney \& Pagola-Carte 2009). Only one specimen of Phalacrotophora fasciata (Fallen, 1823), a parasitoid of Coccinellidae pupae (Disney 1994), was captured in the canopy layer.

Megaselia superciliata, with unknown larval habit and flower-visiting species (Disney 1994), was more abundant in lower strata.

The four saprophagous species, $M$. pectoralis, $M$. pectorella, $M$. diversa, and $D$. florescens (Disney 1994, Buck 1997, Durska et al. 2010), were more abundant in two lower strata, although also were present in the canopy stratum. The polyphagous $M$. longicostalis, have a saprophagous or mycophagous larvae and adult flower-visiting, so that it was scarce in the canopy layer, while the polyphagous $M$. pusilla, with saprophagous and parasitic larvae of Cerambycidae and Coccinellidae, was active in all strata, being dominant in the canopy layer (Buck 1997, Disney 1999). The mycophagous species M. flava (Fallén, 1823), M. flavicans Schmitz, 1935, M. rubella (Schmitz, 1920) and M. berdseni (Schmitz, 1919) had a higher abundance in the herb stratum, where the mushrooms occur (Disney 1994).

\section{ACKNOWLEDGEMENTS}

We acknowledge the Diputación de Barcelona for supporting the entomological project at the Montseny Natural Park in 1990-1991. We would like to thank Dr. Josep Pinyol for their help and advice with multivariate statistical programs. We also acknowledge Dr. Carmen Bach for lending us the LEICA microscope.

\section{REFERENCES}

ANDERSON M. J. 2001 A new method for non-parametric multivariate analysis of variance. Austral Ecology 26: 32-46. ANDERSON M. J., GORLEY R. N. \& CLARKE K. R. 2008 PERMANOVA + for PRIMER: Guide to software and Statistical Methods. PRIMER-E: Plymouth, UK.

BoADA M. 2001 Manifestacions del canvi ambiental global al Montseny. Dissertation. Universidad Autónoma de Barcelona. 430 pp.

BoAdA M. \& Ullastres H. 1998 El macizo del Montseny, guía para visitarlo. Brau Ediciones del Bronce. 110 pp.

BUCK M. 1994: Sphaeroceridae and Phoridae (Diptera) collected by emergence traps from various terrestrial habitats in Southern Germany. Studia Dipterologica 1: 93-106.

BUCK M. 1997 Untersuchungen zur ökologischen Einnischung saprophager Dipteren unter besonderer Berücksichtigung der Phoridae und Sphaeroceridae (Brachycera/ Cyclorrhapha). Dissertation. University of Ulm, 194 pp.

DiSNEY, R. H. L. 1990 Some myths and the reality of scuttle fly biology. Antenna 14(2): 64-67.

DiSNEY R. H. L. 1994 Scuttle flies: the Phoridae. Chapman \& Hall, London, UK. 467 pp.

DisNeY R. H. L. 1999 A troublesome sibling species complex of scuttle flies (Diptera: Phoridae) revisited. Journal of Natural History 33/8: 1159-1216.

Disney R. H. L. \& Pagola-CARTe S. 2009 Two new species of Megaselia Rondani (Diptera: Phoridae) attracted to bracket fungi (Polyporaceae) in Spain. Heteropterus Revista de Entomología 9 (2): 87-95.

Disney R. H. L., Prescher S. \& Ashmole N. P. 2010 Scuttle flies (Diptera: Phoridae) of the Canary Islands. Journal of Natural History 44 (3-4): 107-218.

DURSKA E. 1996 The species composition and structure of scuttle fly communities (Diptera, Phoridae) in mature tree stands in pine forests at different stages of habitat degradation. Fragmenta Faunistica 39 (17-24): $267-285$.

DURSKA E. 2001 Secondary succession of scuttle fly communities (Diptera: Phoridae) in moist pine forest in Białowieża Forest. Fragmenta Faunistica 44: 79-128.

DURSKA E. 2006 Diversity of the scuttle fly (Diptera: Phoridae) communities in the plantations of moist pine forests of the Białowieża Primeval Forest and the Tuchola Forest (Poland). Biodiversity and Conservation 15: 385-393.

DURSKA E. 2015 Effects of fire on scuttle flies (Diptera: Phoridae) in a pine forest in Poland. Entomologica Fennica 26: $181-193$.

DuRSKA E., BONET J. \& ViKLund B. 2010. The scuttle fly (Diptera: Phoridae) assemblages of a wildfire-affected hemiboreal old-growth forest in Tyresta (Sweden). Entomologica Fennica 21(1): 19-32.

GarcíA-Romera C. \& BARRIENTOS J. A. 2014a La fauna de Phoridae (Diptera) en el Parque Natural del Montseny (Cataluña, España). Citas nuevas para la Península Ibérica. Boletín de la Sociedad Entomológica Aragonesa 54: $237-261$.

García-Romera C. \& BARrientos J. A. 2014b Nine new species of Phoridae (Insecta: Diptera) from Spain. Zootaxa 3857 (2): 244-260. 
KAMPICHLER C. \& TESCHNER M. 2002 The spatial distribution of leaf galls of Mikiola fagi (Diptera: Cecidomyiidae) and Neuroterus quercusbaccarum (Hymenoptera: Cynipidae) in the canopy of a Central European mixed forest. European Journal of Entomology 99 (1): 79-84.

Pollet M. \& Grootaert P. 1991 Horizontal and vertical-distribution of Dolichopodidae (Diptera) in a woodland ecosystem. Journal of Natural History 25 (5): 1297-1312.

RoBINSON W. H. 1971 Old and new biologies of Megaselia species (Dipt, Phoridae). Studia Entomologica 14: 321-348.

\section{STRESZCZENIE}

\section{[Warstwowe rozmieszczenie zadrowatych (Diptera, Phoridae) lasu bukowego (Park Narodowy Montseny, Katalonia, Hiszpania)]}

W pracy zostały przedstawione wyniki badań z okresu 1990-1991 nad strukturą zgrupowań zadrowatych (Diptera, Phoridae) zasiedlających trzy warstwy roślinności lasu bukowego w Parku Narodowym Montseny (Katalonia, Hiszpania). W oparciu o zebrany materiał stwierdzono, że względna liczebność i bogactwo gatunkowe zadrowatych koron drzew było znacznie niższe w porównaniu $\mathrm{z}$ warstwą krzewów i ziól, a różnorodność zgrupowań zasiedlających porównywane warstwy (indeks Shannona) nie różniła się istotnie. Gatunki o larwach saprofagicznych dominowały we wszystkich trzech warstwach. Natomiast, liczebność gatunków związanych rozwojowo z grzybami (mykofagi) oraz zoofagów zmniejszała się wraz $\mathrm{z}$ poziomem porównywanych warstw roślinności. We wszystkich warstwach dominowały gatunki z rodzaju Megaselia. Ponadto, M. pectoralis został stwierdzony w grupie dominantów wszystkich trzech warstw roślinności (runo, krzewy, drzewa). 